\title{
Analyzing occupational heat stress using sensor-based monitoring: a wearable approach with environmental ergonomics perspective
}

\author{
M. Sharma ${ }^{1} \cdot$ N. M. Suri ${ }^{1} \cdot$ S. Kant ${ }^{1}$
}

Received: 26 October 2021 / Revised: 6 December 2021 / Accepted: 14 December 2021 / Published online: 28 January 2022

(c) Islamic Azad University (IAU) 2021

\begin{abstract}
Occupational heat stress could impose a greater risk of heat-related morbidities among the exposed users, declining their work productivity and contributing to a financial burden. This necessitate the implementation of adequate preventive measures and control policies to improve the users' well-being and productive capacity. The emergence of modernistic sensors gives rise to workplace heat stress monitoring at a substantially lower cost than expensive conventional equipment. Present work unveils the productive role of sensor-based safety helmet, which could monitor the environmental variables, heat stress indices, and users' physiological variables as an indicator of heat strain. The proposed safety helmet was tested under three different work environments with users' engaged in specific work activities. Notable variations were perceived among the measured data under respective work conditions and physical activity performed. Higher heat risk exposures were attributable to the outdoor condition compared to indoor work conditions. For wet bulb globe temperature index, strong association $(p$-value $<0.01)$ was observed with fighter index of thermal stress $\left(R^{2}\right.$-value $\left.=0.959\right)$ followed by discomfort index $\left(R^{2}\right.$ value $=0.899)$ and heat index $\left(R^{2}\right.$-value $\left.=0.867\right)$. Results revealed a rise in measured physiological parameters under the heavy workload activity (shoveling task; outdoor location) followed by hacksaw cutting task (indoor location), while least values were associated with light workload activity (drilling task; indoor location). The proposed design intervention could be considered an effective site-specific solution for monitoring heat stress exposures and keeping exposed users well aware of the prevalent thermal work conditions at the individual level.
\end{abstract}

Keywords Heat exposure $\cdot$ Occupational safety $\cdot$ Risk assessment $\cdot$ Sensors $\cdot$ Work environment

\section{Introduction}

Heat stress is an unacknowledged occupational health hazard, especially in developing countries, which could impose a greater risk of heat-related morbidities and safety threats among the employed workforce (Krishnamurthy et al. 2017). Hot stressful work conditions influence the humans' physiological responses (such as rise in heart rate, core body temperature, skin temperature, and body mass loss due to sweating). This affects the heat exchange mechanism between user and its surrounding environment, thereby deteriorating

Editorial responsibility: Maryam Shabani.

M. Sharma

ask.milapsharma@gmail.com

1 Department of Production and Industrial Engineering, Punjab Engineering College (Deemed To Be University), Sector 12, Chandigarh 160012, India human health and work productivity (Krishnamurthy et al. 2017; Fahed et al. 2018; Rabeiy 2019). Several environmental factors (air temperature, radiant heat, air velocity, and relative humidity) and individual factors (metabolic rate and clothing worn) contribute to this occupational health hazard and subsequent risk-severity influence the heat-strain experienced by the exposed audience (Djongyang et al. 2010; Aritan 2019; Das and Subudhi 2021). Extreme hot environments are usually widespread in foundries, iron and steel industries, glass manufacturing units, construction worksites, and allied work sectors (Varghese et al. 2018). In developing countries, many indigent laborers are strained by harsh thermal work ambience during the hot summer season, resulting in heat-related health issues, reduced productivity, and economic burden (Kjellstrom et al. 2009, 2019; Krishnamurthy et al. 2017). Apart from acute heat-related issues (like dehydration, exhaustion, heat cramps); chronic issues such as heat stroke, damages at sub-cellular level (Deoxyribonucleic acid (DNA) damage), immunological 
suppressions (decrease in white blood cell counts and lymphocyte levels weakens the user immune system), and risk of renal anomalies (i.e., kidney stones, urethral calculi) are also prevalent among users exposed to high-heat work environments (Venugopal et al. 2019, 2020; Jafari et al. 2020).

Several thermal indices have been developed for assessing the heat stress exposure levels under different work environments. The wet bulb globe temperature (WBGT) index is one of the most widely used in force; due to its applicability under hot work environments (Epstein and Moran 2006). However, for conducting in-depth analysis, it could be used as an initial screening method followed by evaluating the physiological parameters (as indicator of heat strain) based on the recommended standard guidelines and also in conjunction with other widely used heat stress indices (Parsons 2006). This strategy provides a better estimation of the heat strain experienced by the exposed user. There are several available direct indices such as discomfort index (DI), humidex (HD), heat index (HI), fighter index of thermal stress (FITS), which could be considered effective alternatives for assessing the workplace thermal ambience without requiring cumbersome evaluations and costlier equipment (Epstein and Moran 2006; Havenith and Fiala 2011). Also, several valid physiological parameters reflect the heat strain experienced by the user under hot and humid work conditions. However, three physiological parameters, i.e., skin temperature (ST), heart rate (HR), and core body temperature (CBT), are most widely used (Parsons 2019). Inadequate prevention and control policies adversely impact the prevalent conditions, necessitating the need to explore these concerning heat stress/strain parameters rigorously (Varghese et al. 2018). Design control interventions and preventive measures could be considered effective remedial steps in reducing the exposure levels up to the desired permissible limits (Giahi et al. 2016; Sharma et al. 2020), with emphasis on improving the existing thermal work ambience.

The emergence of modernistic sensors gives rise to concise data monitoring and analysis opportunities, enabling real-time smart monitoring and design control actuation systems at a substantially lower cost than expensive conventional equipment in the market (Sawka and Friedl 2018; Sharma et al. 2020). With recent technological advancements (enhancing capabilities in deploying sensor modules for workplace monitoring and predicting user thermal comfort assessment), respective implementation concerns are gaining importance in industrialized developing countries to keep the targeted audience well aware of the prevalent thermal conditions (Devi and Roy 2017; Chen et al. 2018; Jha and Tukkaraja 2020). Several leading manufacturers have recently introduced low-cost environmental sensors with tremendous integration capabilities with microcontroller units to perform specific desired operations. Furthermore, several studies have implemented advanced sensor modules with
Arduino microcontroller to serve as a low-cost data acquisition system with potential benefits such as easier implementation, open-source availability, compactness, energy savings, quick response rate, good reliability and precision level (Das et al. 2017; Devi and Roy 2017; Chen et al. 2018; Sawka and Friedl, 2018; Aryal and Becerik-Gerber, 2019; Jha and Tukkaraja, 2020; Sharma et al. 2020; Deniz et al. 2021). Due to these potential benefits, there has been an increasing trend in implementing prototype systems demonstrating various industrial applications and educational purposes. So, the present work aims at (i) Design and development of a sensor-based safety helmet that could monitor the environmental factors, heat stress indices, and users' physiological variables as an indicator of heat strain. (ii) Analyzing the proposed device under different work conditions followed by descriptive and inferential statistics on the evaluated parameters.

The work has been divided into several sections. Section 2 briefs the work methodology including details regarding considered heat stress parameters, materials/equipment, sensors/hardware modules, and data monitoring. Section 3 explains the result findings of the present study, followed by Sect. 4, describing the discussion of findings along with study limitations. Finally, Sect. 5 concludes the study work with future research directions. The present study was conducted during the month of July-August 2021 in Chandigarh union territory of India.

\section{Materials and methods}

The workflow for the present research study has been depicted in Fig. 1. Current work unveils the efficacious role of the sensor-based approach in analyzing heat stress parameters at the individual level. The proposed design intervention (sensor-based safety helmet) was tested under three different work environments with users performing specific work activities. Environmental variables (dry-bulb temperature $\left(T_{a}\right)$, relative humidity $(R H)$, wet-bulb temperature $\left(T_{w}\right)$, globe temperature $\left(T_{g}\right)$ ), heat stress indices (DI, WBGT, HI, FITS), and users' physiological variables (eardrum temperature as CBT indicator, ST, and HR) were monitored under respective work locations using the proposed device and standardized equipment respectively.

\section{Considered heat stress indices}

Apart from WBGT index, considered heat stress indices includes several widely used indices, namely DI, HI, FITS, and WBGT approximation by the Australian Bureau of metrology (ABM). The selected indices mostly rely on the combined effects of dry-bulb temperature, relative humidity and wet-bulb temperature values. Primary variables $\left(T_{a}\right.$ 
Fig. 1 Work flowchart for the present study

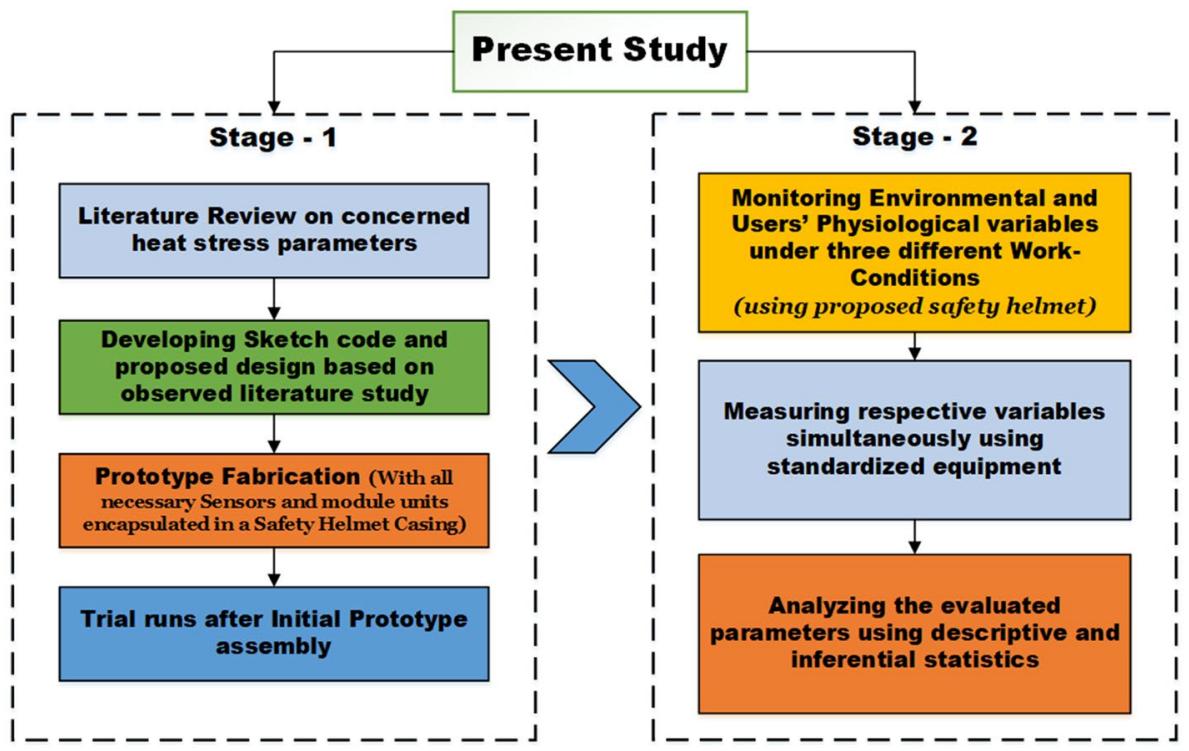

and $R H$ ) were used to derive the secondary variables, i.e., $T_{w}$ and vapor pressure $\left(V_{p}\right)$, based on the mathematical expressions proposed by previous research findings (Australian Bureau of Metrology 2010; Stull 2011). After that, respective variables were used in conjunction to evaluate the considered heat stress indices. Table 1 illustrates the risk range classifications for considered heat stress indices and physiological variables as heat strain indicators.

\section{Wet bulb globe temperature (WBGT)}

International Organization for Standardization (ISO) 7243 standard provides an assessment methodology for analyzing heat stress under hot work environments utilizing WBGT; considering the effects of radiant temperature (using a black-globe thermometer, i.e., $T_{g}$ ), natural wet bulb temperature $\left(T_{n w}\right)$, and $T_{a}$ in degree Celsius. The

Table 1 Risk range classifications for heat stress indices and physiological parameters

\begin{tabular}{|c|c|c|c|c|c|c|}
\hline \multicolumn{7}{|c|}{ Heat stress indices (risk range classifications) } \\
\hline $\begin{array}{l}\text { Discomfort index } \\
\text { (DI) (Sohar et al. } \\
\text { 1962) }\end{array}$ & $\begin{array}{l}<21^{\circ} \mathrm{C} \text { no dis- } \\
\text { comfort }\end{array}$ & $\begin{array}{l}21 \text { to }<24^{\circ} \mathrm{C} \text { less } \\
\text { than half popula- } \\
\text { tion feel discomfort }\end{array}$ & $\begin{array}{l}24 \text { to }<27{ }^{\circ} \mathrm{C} \text { more } \\
\text { than half popula- } \\
\text { tion feel discom- } \\
\text { fort }\end{array}$ & $\begin{array}{l}27 \text { to }<29{ }^{\circ} \mathrm{C} \text { most } \\
\text { population feel } \\
\text { discomfort }\end{array}$ & $\begin{array}{l}29 \text { to }<32{ }^{\circ} \mathrm{C} \\
\text { everyone feel } \\
\text { discomfort }\end{array}$ & $\begin{array}{l}\geq 32{ }^{\circ} \mathrm{C} \text { state of } \\
\text { medical emer- } \\
\text { gency }\end{array}$ \\
\hline $\begin{array}{l}\text { Wet bulb globe } \\
\text { temperature } \\
\text { (WBGT) (Blaze- } \\
\text { jczyk et al. 2012) }\end{array}$ & $<18^{\circ} \mathrm{C}$ no danger & 18 to $<23{ }^{\circ} \mathrm{C}$ warm & 23 to $<28^{\circ} \mathrm{C}$ hot & $\begin{array}{l}28 \text { to }<30^{\circ} \mathrm{C} \text { very } \\
\text { hot }\end{array}$ & $\geq 30{ }^{\circ} \mathrm{C}$ swelt & \\
\hline $\begin{array}{l}\text { Heat index (HI) } \\
\text { (Steadman 1979; } \\
\text { Rothfusz 1990) }\end{array}$ & $\begin{array}{l}27 \text { to }<32{ }^{\circ} \mathrm{C} \mathrm{cau}- \\
\text { tion }\end{array}$ & $\begin{array}{l}32 \text { to }<41^{\circ} \mathrm{C} \\
\text { extreme caution }\end{array}$ & $\begin{array}{l}41 \text { to }<54{ }^{\circ} \mathrm{C} \\
\text { danger }\end{array}$ & $\begin{array}{l}>54^{\circ} \mathrm{C} \text { extreme } \\
\text { danger }\end{array}$ & & \\
\hline $\begin{array}{l}\text { Fighter index of } \\
\text { thermal stress } \\
\text { (FITS) (Nunne- } \\
\text { ley and Stribley } \\
\text { 1978) }\end{array}$ & $<31{ }^{\circ} \mathrm{C}$ normal & 32 to $38{ }^{\circ} \mathrm{C}$ caution & $\geq 38^{\circ} \mathrm{C}$ danger & & & \\
\hline \multicolumn{7}{|c|}{ Heat strain (physiological parameters) (ISO 9886 2004; Parsons 2019) } \\
\hline $\begin{array}{l}\text { Core body tempera- } \\
\text { ture }(\mathrm{CBT})\end{array}$ & \multicolumn{6}{|c|}{$\begin{array}{l}\text { Normal CBT: } 37{ }^{\circ} \mathrm{C} \text {; CBT within } 38-39^{\circ} \mathrm{C} \text { : risk of exhaustion increases; CBT above } 39^{\circ} \mathrm{C} \text { : failure of the ther- } \\
\text { moregulatory system may occur; CBT above } 42^{\circ} \mathrm{C} \text { : even death could occur. For acclimatized workers, CBT limit } \\
\text { value }>38.5^{\circ} \mathrm{C} \text { could be tolerated; however } \mathrm{CBT} \text { rise }>39^{\circ} \mathrm{C} \text { is not acceptable }\end{array}$} \\
\hline Heart rate (HR) & \multicolumn{6}{|c|}{ The HR limit $\left(\mathrm{HR}_{\mathrm{L}}\right)$ value at the workplace can be evaluated by the relation: $\mathrm{HR}_{\mathrm{L}}=\left(185-0.65^{*}\right.$ age $)$} \\
\hline $\begin{array}{l}\text { Skin temperature } \\
\text { (ST) }\end{array}$ & \multicolumn{6}{|c|}{ For hot work conditions, threshold limit value for local skin temperature $\left(\mathrm{T}_{\mathrm{Lsk}}\right)$ is $43^{\circ} \mathrm{C}$} \\
\hline
\end{tabular}


modified standard also includes the effects of worn clothing in terms of clothing adjustment values (CAV) and

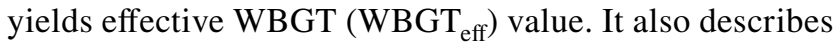
WBGT reference values for performed work activity based on the metabolic rate classifications (ISO 7243 2017).

For Indoor environment; WBGT $=0.7 T_{\mathrm{nw}}+0.3 T_{g}$

For outdoor environment; WBGT $=0.7 T_{\mathrm{nw}}+0.2 T_{g}+0.1 T_{a}$

With clothing effect; $\mathrm{WBGT}_{\text {eff }}=\mathrm{WBGT}+\mathrm{CAV}$

However, few WBGT approximation models (also being widely used) have been provided by the Australian Bureau of metrology and the Liljegren model (Lemke and Kjellstrom 2012); where the ABM model offers a more straightforward approach solely relying on two variables, i.e., $T_{a}\left(\right.$ in $\left.^{\circ} \mathrm{C}\right)$ and $R H$ (in percent) as depicted in Eq. (4), while Liljegren model considers additional inputs from several other variables also, i.e., solar radiation and wind speed. However, approximations provided by the ABM model could under-estimate/ over-estimate the WBGT values if standard assumptions criteria are not fulfilled (Grundstein and Cooper 2018).
HI value computed by the regression equation is limited by an error value of $\pm 1.3^{\circ} \mathrm{F}$. The regression equation considered a few adjustments/correction factors for two conditions.

If $R H<13 \%$ and $T_{a}$ varies between $80^{\circ} \mathrm{F}$ to $112^{\circ} \mathrm{F}$, the following adjustment is subtracted from the regression equation.

Adjustment_1 $=[(13-\mathrm{RH}) / 4] *\left[\left(17-\left|T_{a}-95\right|\right) / 17\right]^{1 / 2}$

On the other hand, if the $R H>85 \%$ and $T_{a}$ varies between $80^{\circ} \mathrm{F}$ to $87^{\circ} \mathrm{F}$, the following adjustment is added to the regression equation.

Adjustment_2 $=\left[\frac{\mathrm{RH}-85}{10}\right] *\left[\frac{87-T_{a}}{5}\right]$

\section{Fighter index of thermal stress (FITS)}

FITS index (for assessing heat stress among US air force personnel in hot weather) was derived from the WBGT, considering the combination of $T_{w}$ and $T_{a}$ in ${ }^{\circ} \mathrm{C}$ (Nunneley and Stribley 1978).

$\mathrm{WBGT}^{\mathrm{ABM}}=0.567 \times T_{a}+0.393 \times\left[\frac{\mathrm{RH}}{100} \times 6.105 \times \exp \left(17.27 \times \frac{T_{a}}{\left(237.7+T_{a}\right)}\right)\right]+3.94$

\section{Discomfort index (DI)}

It is a direct indices tool (based on the $T_{a}$ and $T_{w}$ values in ${ }^{\circ} \mathrm{C}$, with some correction factor) that relates the thermal degree of discomfort the user perceives in a work environment (Sohar et al. 1962).

$\mathrm{DI}=0.5\left(T_{a}+T_{w}\right)$

\section{Heat index (HI)}

$\mathrm{HI}$ is another popular index used to assess hot environments involving using a regression equation based on two environmental factors, i.e., $R H$ in percent and $T_{a}$ in degree Fahrenheit (Rothfusz 1990). The developed regression equation (Eq. 6) by Rothfusz is based on the results provided by the Steadman heat model (Steadman 1979).

$$
\begin{aligned}
\mathrm{HI}= & -42.379+2.04901523 * T_{a}+10.14333127 * \mathrm{RH} \\
& -0.22475541 * T_{a} * \mathrm{RH}-0.00683783 * T_{a}{ }^{2} \\
& -0.05481717 * \mathrm{RH}^{2}+0.00122874 * T_{a}{ }^{2} * \mathrm{RH} \\
& +0.00085282 * T_{a} * \mathrm{RH}^{2}-0.00000199 * T_{a}{ }^{2} * \mathrm{RH}^{2}
\end{aligned}
$$

FITS $=0.83 * T_{w}+0.35 * T_{a}+5.08$

\section{Wet-bulb temperature $\left(T_{w}\right)$}

Stull (2011) presented an empirical expression (Eq. 10) for calculating the wet-bulb temperature based on the $T_{a}$ and $R H$ values. The derived equation (where, arctan in radians; $R H$ in $\% ; T_{a}$ in $\left.{ }^{\circ} \mathrm{C}\right)$ is valid for specific $R H(5 \%$ to $99 \%)$ and $T_{a}$ values $\left(-22{ }^{\circ} \mathrm{C}\right.$ to $\left.50{ }^{\circ} \mathrm{C}\right)$, except for situations with low humidity and extreme cold temperature (Stull 2011).

$$
\begin{aligned}
T_{w}= & T_{a} * \arctan \left[0.151977 *(\mathrm{RH}+8.313659)^{\frac{1}{2}}\right] \\
& +\arctan \left(T_{a}+\mathrm{RH}\right)-\arctan (\mathrm{RH}-1.676331) \\
& +0.00391838 * \mathrm{RH}^{\frac{3}{2}} * \arctan (0.023101 * \mathrm{RH})-4.686035
\end{aligned}
$$

\section{Sensors and hardware modules}

In the present study, several sensor modules (brand-new sensors acquired from genuine and commercial suppliers) were utilized for evaluating the intended variables and heat stress indices. Respective sensor units includes DHT22; Aosong Electronics Co. Ltd. (ASAIR) (for monitoring environmental 
variables; range: $-40{ }^{\circ} \mathrm{C}$ to $80{ }^{\circ} \mathrm{C} T_{a} ; 0 \%$ to $100 \% R H$, accuracy: $\pm 0.5^{\circ} \mathrm{C} T_{a} ; \pm 5 \% R H$, resolution: $0.1{ }^{\circ} \mathrm{C} T_{a} ; 0.1 \% R H$ ), whereas for physiological monitoring sensor unit includes: LM35; Texas instruments (for measuring body skin-surface temperature; range: $-55^{\circ} \mathrm{C}$ to $+150^{\circ} \mathrm{C}$, accuracy: $\pm 0.75^{\circ} \mathrm{C}$, resolution: $0.1^{\circ} \mathrm{C}$ ), MLX90614; Melexis infra-red temperature sensor (for measuring eardrum temperature; an effective indicator of CBT as eardrum shares blood supply with the hypothalamus (temperature control centre in the brain); range: $-40{ }^{\circ} \mathrm{C}$ to $+125^{\circ} \mathrm{C}$, accuracy: $\pm 0.5^{\circ} \mathrm{C}$, resolution: $0.02{ }^{\circ} \mathrm{C}$ ), and MAX30102; Maxim integrated pulse oximetry and heart-rate sensor (for monitoring heart rate activity, in beats per minute (bpm)). These sensors were selected based on several factors such as compact size, low cost, industrial applicability, accuracy and resolution levels, and ease of use. For monitoring the concerned physiological variables (i.e., CBT, HR, and ST as indicators of heat strain), respective sensor units were placed on specific measurement location sites as depicted in Fig. 2 (for CBT: eardrum temperature was measured by inserting MLX90614 temperature sensor probe inside users' ear canal; for ST: ear skin temperature was measured using LM35 sensor placed on outer ear pinna region; for HR: MAX30102 heart rate sensor was placed on ear lobule region). Simultaneously, concerned parameters (heat-stress/physiological variables) were also measured utilizing the standardized monitoring equipment, with detailed specifications described in Table 2.

In the present study, Arduino Mega 2560 was implemented as the microcontroller unit based on several concerns better suiting the current application purpose, such as broader module connectivity, sufficient flash memory, and easier integration capabilities. It is programmable using the Arduino software integrated development environment (IDE) via universal serial bus (USB) communication. Several supporting hardware modules were also utilized (performing specific functions) in conjunction with the microcontroller board and sensor units, including the micro-SD card module (for data logging), buzzer/LED indicator, HC-05 Bluetooth module, and $9 \mathrm{~V}$ DC power source. The monitored readings could directly be stored into the data logging module in.csv format using specific sketch code, which may be further imported in Microsoft Excel for data analysis. The main logic of the written sketch code consists of essential parts such that each of them performs a particular duty. The combination of these parts allows reading the data from sensors and the microcontroller eventually performing data logging for further processing, alerting user via early warning signals, and further displaying them on the android app as assisted by the user. Several electronics blogs, websites, datasheets, and module libraries were utilized while constructing the respective sketch code.

The sketch code was constructed using Arduino IDE Genuino 1.8.2; with some important parts of the sketch code includes various sub-sections like utilizing libraries, monitoring primary variables from the sensors, calculating secondary variables w.r.t the relationship with primary variables, evaluating heat stress indices based on the primary and secondary variables, data logging variables and evaluated heat stress indices, and checking for any initialization error during program run. A branded safety helmet (ratchet type; head size: $540 \mathrm{~mm}$ to $600 \mathrm{~mm}$ ) was procured from the market. All respective sensors and hardware modules were encapsulated in the helmet casing as described in Fig. 3.

\section{Data monitoring}

Data monitoring was conducted under three different work conditions (with subject performing specific work activity), i.e., Location 1: Indoor work-environment (manual hacksaw operation; moderate metabolic workload), Location 2:
Fig. 2 Measurement locations for respective physiological parameters
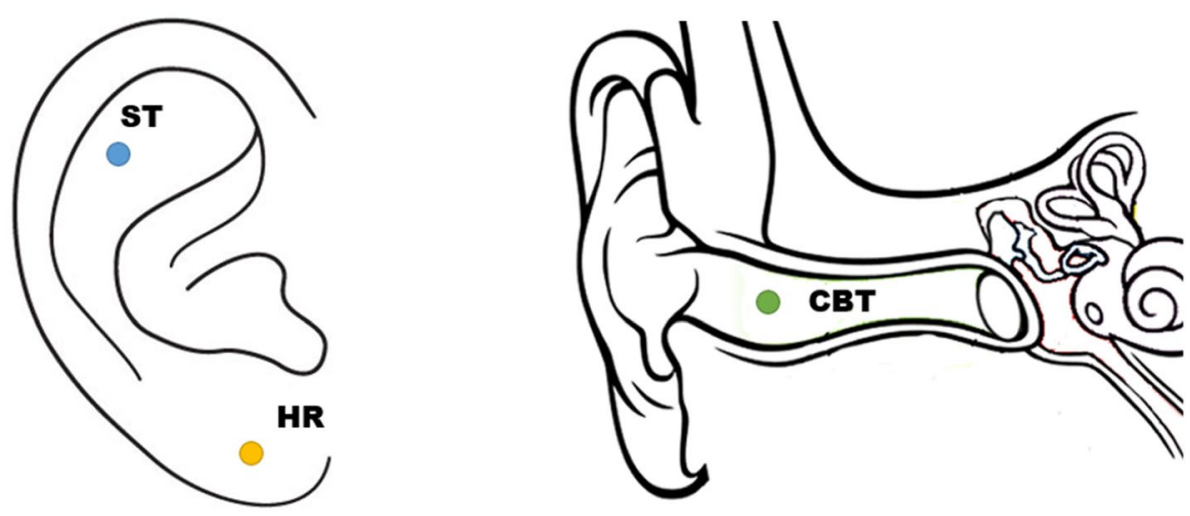

ST: Skin Temperature, HR: Heart Rate, CBT: Core Body Temperature 
Table 2 Detailed specifications for considered instruments

\begin{tabular}{|c|c|c|c|}
\hline Equipment & Parameters & Range/resolution/accuracy & Category \\
\hline $\begin{array}{l}\text { Kestrel } 5400 \text { Heat stress Tracker Pro } \\
\text { with vane mount } \\
\text { Nielsen-Kellerman Co.; } \\
\text { USA }\end{array}$ & $\begin{array}{l}\text { Dry-bulb Temperature }\left(T_{a}\right), \\
\text { Relative Humidity }(R H), \\
\text { Globe Temperature }\left(T_{g}\right), \\
\text { Air Velocity }\left(V_{a r}\right) \\
\text { Dew-point Temperature }\left(T_{d p}\right) \text {, } \\
\text { Wet-bulb Temperature }\left(T_{w}\right)\end{array}$ & $\begin{array}{l}T_{a}:-29.0 \text { to } 70.0^{\circ} \mathrm{C} ;\left(0.1{ }^{\circ} \mathrm{C}\right) ; \\
\quad\left( \pm 0.5^{\circ} \mathrm{C}\right) \\
R H: 10 \text { to } 90 \% ;(0.1 \%) ;( \pm 2 \%) \\
T_{g}:-29.0 \text { to } 60 .{ }^{\circ} \mathrm{C} ;\left(0.1{ }^{\circ} \mathrm{C}\right) ; \\
\quad\left( \pm 1.4{ }^{\circ} \mathrm{C}\right) \\
V_{a r}: 0.6 \text { to } 40.0 \mathrm{~m} / \mathrm{s} ;(0.1 \mathrm{~m} / \mathrm{s}) ; \text { Larger } \\
\text { of: } 3 \% \text { of reading, least significant } \\
\text { digit or } 20 \mathrm{ft} / \mathrm{min} \\
T_{d p}: \text { not specified }\left( \pm 1.9{ }^{\circ} \mathrm{C}\right) ;\left(0.1^{\circ} \mathrm{C}\right) \\
T_{w}: \text { not specified }\left( \pm 0 .{ }^{\circ} \mathrm{C}\right) ;\left(0.1^{\circ} \mathrm{C}\right)\end{array}$ & Environmental parameters \\
\hline $\begin{array}{l}\text { Braun Thermoscan } 7 \text { IRT } 6520 \\
\text { Braun; Germany }\end{array}$ & $\begin{array}{l}\text { Core body temperature; } \\
\text { Tympanic membrane /Eardrum } \\
\text { temperature }\end{array}$ & $\begin{array}{l}34-42.2^{\circ} \mathrm{C} \text { (range); } 0.1{ }^{\circ} \mathrm{C} \text { (resolu- } \\
\text { tion); } \\
\pm 0.2{ }^{\circ} \mathrm{C}: 35-42{ }^{\circ} \mathrm{C} ; \pm 0.3{ }^{\circ} \mathrm{C} \text { : outside } \\
\text { this range (accuracy) }\end{array}$ & Physiological parameters \\
\hline $\begin{array}{l}\text { Omron HEM } 6181 \text { Wrist Blood Pres- } \\
\text { sure Monitor }\end{array}$ & $\begin{array}{l}\text { Blood Pressure (BP) (Systolic (SYS); } \\
\text { Diastolic (DIA)), Heart Rate }\end{array}$ & $\begin{array}{l}\text { Cuff pressure range: } 0 \text { to } 299 \mathrm{mmHg} \\
\text { Blood pressure measurement range: } \\
\text { SYS: } 60 \text { to } 260 \mathrm{mmHg} \text {; DIA: } 40 \text { to } \\
215 \mathrm{mmHg} \\
\text { Pulse measurement range: } 40 \text { to } \\
180 \mathrm{bpm} \\
\text { Accuracy Pressure: } \pm 3 \text { mmHg } \\
\text { Pulse: } \pm 5 \% \text { of display reading }\end{array}$ & \\
\hline Pulse oximeter & $\begin{array}{l}\text { Heart Rate, Oxygen saturation } \\
\quad\left(\mathrm{SpO}_{2}\right)\end{array}$ & $\begin{array}{l}\text { Pulse rate: } 30-250 \mathrm{bpm} \text { (range); } \\
1 \mathrm{bpm} \text { (resolution); } \pm 1 \mathrm{bpm} \text { (accu- } \\
\text { racy) } \\
\text { Haemoglobin saturation: } 35-100 \% \text {; } \\
1 \% ; \pm 3 \%(70-100 \%)\end{array}$ & \\
\hline $\begin{array}{l}\text { Beurer FT85 Infrared } \\
\text { thermometer }\end{array}$ & Skin temperature & $\begin{array}{l}34-42.2^{\circ} \mathrm{C} \text { (range); } 0.1^{\circ} \mathrm{C} \text { (resolu- } \\
\quad \text { tion); } \\
\pm 0.2^{\circ} \mathrm{C} \text { (accuracy) }\end{array}$ & \\
\hline
\end{tabular}

Outdoor work-environment (shoveling task; heavy metabolic workload), and Location 3: Indoor work-environment (drilling/screw-driving task; light metabolic workload). The work activities were classified based on the recommendations provided by ISO 8996 standard (ISO 8996, 2004). The environmental and physiological variables were measured based on the recommended guidelines given by ISO 7243 (ISO 7243, 2017) and ISO 9886 standards (ISO 9886, 2004). The present study was performed in July-August 2021 in Chandigarh union territory of India $\left(30^{\circ} 44^{\prime} 14 \mathrm{~N} ; 76^{0} 47^{\prime}\right.$ $14 \mathrm{E})$; during the afternoon period (12.30 PM to 3.30 PM). A total of 12 male subjects (university students) voluntarily participated in the present study. All participants were informed about the study objectives, and written consent was requested.

The participants were given formal training on the performed work tasks before the study. The study protocol was approved by the student research committee (SRC) of the production and industrial engineering department, Punjab Engineering College, Chandigarh. All subjects were male participants with demographic characteristics as; Age (in years): mean (26.58), SD (3.117), range (22-31); Stature (in cm): mean (171.10), SD (5.569), range (162.7-182.9); Weight (in $\mathrm{Kg}$ ): mean (61.46), SD (5.227), range (54.3-70.2). Before field measurements, the respective sensor units and Kestrel 5400 heat stress tracker were kept initially to stabilize for a minimum period of 15-20 min concerning the targeted work environment, with data points monitored at a sampling interval of $10 \mathrm{~s} /$ each reading. The performed work task details were as follows: (i) Location 1: indoor work-environment (moderate metabolic work-activity; user performing sawing operation (using hand hacksaw) on $5 \mathrm{~mm}$ thick metallic workpiece) (ii) Location 2: outdoor work-environment (heavy metabolic work-activity; user performing sand shoveling task weighing 8-9 kg) (iii) Location 3: indoor work-environment (light metabolic work-activity; user performing drilling and screw-driving task on a wooden block). The Kestrel 5400 heat stress monitor was mounted on a tripod at $1.7 \mathrm{~m}$ floor surface height for environmental monitoring. For physiological monitoring, CBT (eardrum temperature), ST, and HR were recorded at an interval of $2.5 \mathrm{~min}$ during the performed work activity, whereas BP (systolic and diastolic) was measured at 5 min, respectively. Each participant performed the respective work activity for an approximate period of $30 \mathrm{~min}$. Based on clothing worn 


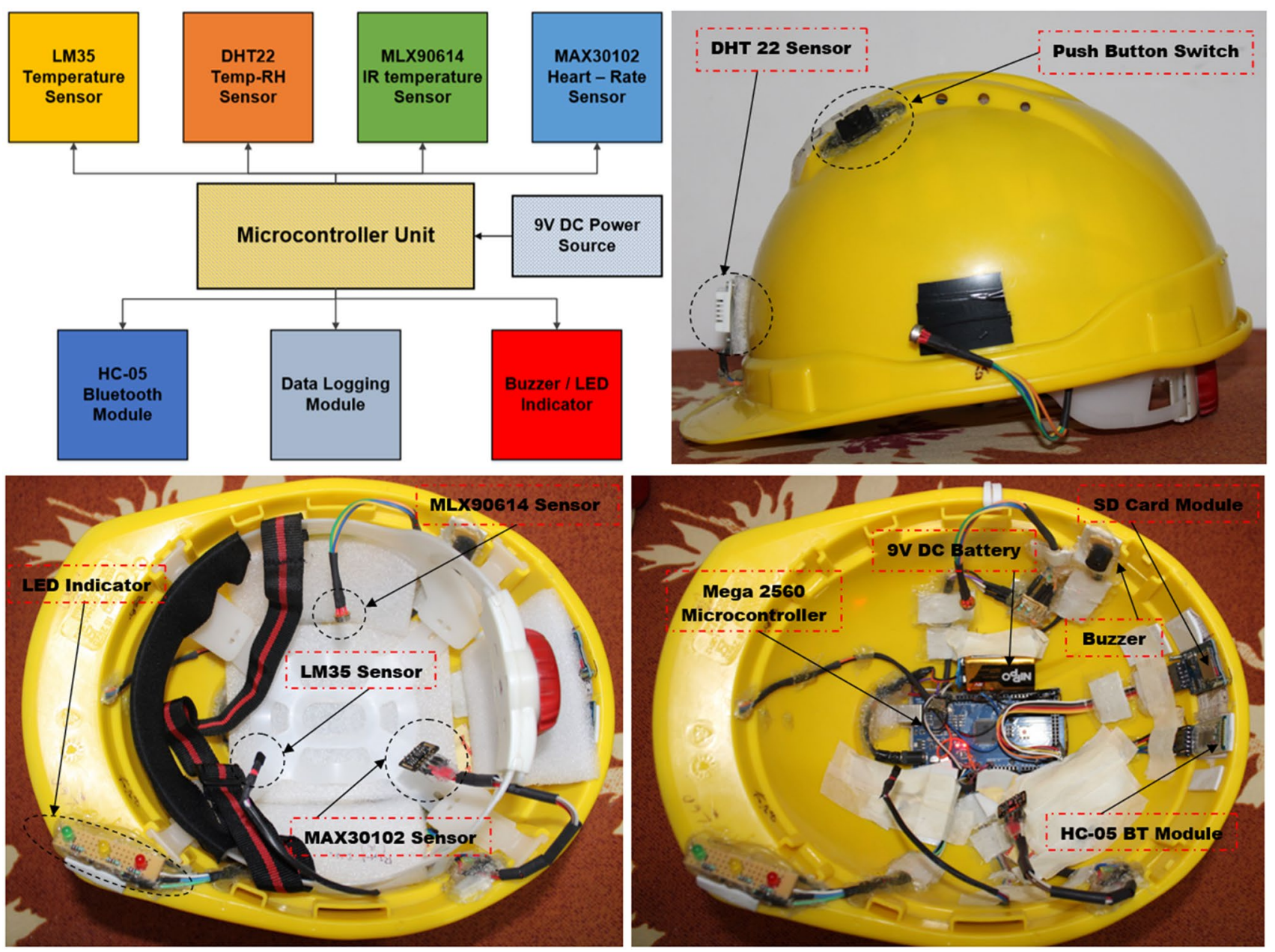

Fig. 3 Proposed safety helmet encapsulated with respective sensors and hardware modules

by the participants, observed clothing insulation value (in clo) as per ISO 9920 standard (ISO 9920 2009) was varying from 0.56 to 0.61 clo. As all participants were wearing cotton clothing, the respective WBGT CAV adjustment (based on ISO 7243:2017 standard) was equal to 0 ; therefore, $\mathrm{WBGT}_{\text {eff }}$ value w.r.t CAV addition remained unaltered.

\section{Statistical analysis}

After conducting the field study, measured variables were analyzed using descriptive and inferential statistics. Monitored data was analyzed using Microsoft Excel 2016 and IBM SPSS 26 software package. Descriptive statistics like mean, standard deviation, and range were used to shed further light on the studied environmental parameters, heat indices, and physiological parameters for the considered work locations. Also, to summarize data precisely and draw meaningful conclusions regarding the variability of individual observations within the respective work conditions. Further, inferential statistics (i.e., Pearson product-moment correlation) were conducted to determine the relationships between heat stress indices and users' physiological parameters, and between respective heat indices themselves.

\section{Results and discussion}

Table 3 depicts the mean, standard deviation, and range values of the monitored data, i.e., environmental variables $\left(T_{a}\right.$, $R H, T_{w}, T_{g}, V_{a r}$ ), heat stress indices (DI, HI, FITS, WBGT), and users' physiological responses (CBT, ST, HR, BP); using proposed safety helmet ( $\mathrm{SH})$ and standard equipment (EQ) respectively. For environmental monitoring, higher average values for dry and wet bulb temperatures were observed under the outdoor work condition (location 2) for both the proposed device and standard equipment. 
Table 3 Descriptive statistics results for monitored variables under respective work locations

\begin{tabular}{|c|c|c|c|c|c|c|}
\hline \multirow{2}{*}{$\begin{array}{l}\text { Mean (SD) } \\
\text { Range }\end{array}$} & \multicolumn{2}{|l|}{ Location 1} & \multicolumn{2}{|l|}{ Location 2} & \multicolumn{2}{|l|}{ Location 3} \\
\hline & SH & EQ & SH & EQ & SH & EQ \\
\hline \multicolumn{7}{|c|}{$\begin{array}{l}\text { Environmental variables ( } T_{a}, T_{w}, T_{g} \text { in degree Celsius; } R H \text { in percent; } V_{a r} \text { in meter per second) (NA: not applicable) (Note: monitored range } \\
\text { values presented in italics) }\end{array}$} \\
\hline$T_{a}$ & 34.89 (0.691) 33.9-35.7 & $\begin{array}{l}35.19(0.682) \\
33.8-36.0\end{array}$ & $\begin{array}{l}36.57(0.683) \\
35.4-38.0\end{array}$ & $\begin{array}{l}36.13(0.711) \\
34.1-38.1\end{array}$ & $\begin{array}{l}33.66(0.312) \\
32.9-34.4\end{array}$ & $\begin{array}{l}33.73(0.485) \\
32.3-34.7\end{array}$ \\
\hline$R H$ & $\begin{array}{l}59.94(1.460) \\
57.8-64.1\end{array}$ & $\begin{array}{l}56.75(2.112) \\
48.6-63.9\end{array}$ & $\begin{array}{l}65.28(2.491) \\
59.4-70.5\end{array}$ & $\begin{array}{l}64.90(2.248) \\
59.2-70.5\end{array}$ & $\begin{array}{l}69.15(1.981) \\
66.2-76.9\end{array}$ & $\begin{array}{l}66.40(2.228) \\
61.8-73.1\end{array}$ \\
\hline$T_{w}$ & $\begin{array}{l}28.38(0.838) \\
27.16-29.57\end{array}$ & $\begin{array}{l}28.18(0.776) \\
26.0-29.1\end{array}$ & $\begin{array}{l}30.87(0.351) \\
30.07-31.95\end{array}$ & $\begin{array}{l}30.61(0.726) \\
28.4-32.2\end{array}$ & $\begin{array}{l}28.86(0.173) \\
28.51-29.42\end{array}$ & $\begin{array}{l}28.65(0.236) \\
28.1-29.2\end{array}$ \\
\hline$T_{g}$ & NA & $\begin{array}{l}35.15(0.743) \\
32.6-36.1\end{array}$ & NA & $\begin{array}{l}43.39(2.364) \\
33.6-47.3\end{array}$ & NA & $\begin{array}{l}34.07(0.583) \\
31.6-35.1\end{array}$ \\
\hline$V_{a r}$ & NA & $\begin{array}{l}0.434(0.266) \\
0-1.5\end{array}$ & NA & $\begin{array}{l}0.849(0.637) \\
0-5.7\end{array}$ & NA & $\begin{array}{l}0.424(0.214) \\
0-0.8\end{array}$ \\
\hline \multicolumn{7}{|c|}{ Heat stress indices (WBGT, DI, FITS, HI in degree Celsius; ${ }^{@}$ WBGT ABM approximation; ${ }^{\wedge}$ WBGT standard expression) } \\
\hline WBGT & $\begin{array}{l}36.86^{@}(1.150) \\
35.19-38.48\end{array}$ & $\begin{array}{l}30.27^{\wedge}(0.737) \\
28.1-31.1\end{array}$ & $\begin{array}{l}40.34^{@}(0.575) \\
39.11-42.06\end{array}$ & $\begin{array}{l}33.72^{\wedge}(0.952) \\
30.9-35.7\end{array}$ & $\begin{array}{l}37.15^{@}(0.224) \\
36.66-37.73\end{array}$ & $\begin{array}{l}30.28^{\wedge}(0.300) \\
28.9-30.8\end{array}$ \\
\hline DI & $\begin{array}{l}31.64(0.760) \\
30.53-32.63\end{array}$ & $\begin{array}{l}31.62(0.684) \\
30.13-32.30\end{array}$ & $\begin{array}{l}33.72(0.482) \\
32.76-34.92\end{array}$ & $\begin{array}{l}33.37(0.537) \\
31.75-34.95\end{array}$ & $\begin{array}{l}31.26(0.181) \\
30.91-31.76\end{array}$ & $\begin{array}{l}31.19(0.321) \\
30.21-31.79\end{array}$ \\
\hline FITS & $\begin{array}{l}40.85(0.933) \\
39.48-42.12\end{array}$ & $\begin{array}{l}40.69(0.826) \\
38.88-41.51\end{array}$ & $\begin{array}{l}43.50(0.491) \\
42.47-44.86\end{array}$ & $\begin{array}{l}43.13(0.678) \\
41.03-44.90\end{array}$ & $\begin{array}{l}40.81(0.184) \\
40.40-41.32\end{array}$ & $\begin{array}{l}40.66(0.320) \\
39.73-41.35\end{array}$ \\
\hline HI & $\begin{array}{l}44.81(2.595) \\
41.13-48.54\end{array}$ & $\begin{array}{l}44.15(2.118) \\
39.62-46.35\end{array}$ & $\begin{array}{l}53.27(1.482) \\
50.12-57.81\end{array}$ & $\begin{array}{l}51.41(1.864) \\
45.62-56.67\end{array}$ & $\begin{array}{l}45.22(0.533) \\
44.03-46.64\end{array}$ & $\begin{array}{l}44.15(0.857) \\
41.76-46.07\end{array}$ \\
\hline \multicolumn{7}{|c|}{ Physiological parameters (CBT, ST in degree Celsius; HR in beats per minute; $\mathrm{BP}$ in $\mathrm{mmHg}$ ) } \\
\hline CBT & $\begin{array}{l}37.64(0.190) \\
37.17-38.06\end{array}$ & $\begin{array}{l}37.50(0.183) \\
37.0-37.9\end{array}$ & $\begin{array}{l}38.13(0.172) \\
37.78-38.61\end{array}$ & $\begin{array}{l}37.96(0.145) \\
37.7-38.3\end{array}$ & $\begin{array}{l}37.00(0.127) \\
36.71-37.35\end{array}$ & $\begin{array}{l}36.79(0.159) \\
36.5-37.2\end{array}$ \\
\hline ST & $\begin{array}{l}36.94(0.179) \\
36.42-37.53\end{array}$ & $\begin{array}{l}37.17(0.150) \\
36.8-37.4\end{array}$ & $\begin{array}{l}37.46(0.252) \\
36.85-38.12\end{array}$ & $\begin{array}{l}37.34(0.161) \\
36.9-37.6\end{array}$ & $\begin{array}{l}36.12(0.325) \\
35.36-36.90\end{array}$ & $\begin{array}{l}36.44(0.338) \\
35.4-37.0\end{array}$ \\
\hline HR & $\begin{array}{l}106.37(15.40) \\
64-156\end{array}$ & $\begin{array}{l}118.55(11.15) \\
97-151\end{array}$ & $\begin{array}{l}120.90(23.36) \\
57-178\end{array}$ & $\begin{array}{l}133.58(11.30) \\
109-165\end{array}$ & $\begin{array}{l}83.70(14.15) \\
39-129\end{array}$ & $\begin{array}{l}84.54(8.955) \\
67-107\end{array}$ \\
\hline \multirow[t]{2}{*}{ BP } & NA & $\begin{array}{l}125.19(7.607) \\
112-144\end{array}$ & NA & $\begin{array}{l}127.08(8.072) \\
112-146\end{array}$ & NA & $\begin{array}{l}122.19(8.648) \\
110-141\end{array}$ \\
\hline & NA & $\begin{array}{l}79.97(7.710) \\
67-101\end{array}$ & NA & $\begin{array}{l}81.08(7.450) \\
66-97\end{array}$ & NA & $\begin{array}{l}78.89(8.457) \\
67-100\end{array}$ \\
\hline
\end{tabular}

Also, recorded values for globe temperature and air velocity were higher under location 2 ; than the other two work conditions. However, a higher value of $R H$ was associated with the indoor work condition (location 3 ), followed by location 2 and location 1, respectively. Figure 4 shows the boxplot graphs for the monitored environmental variables under three different work conditions using the proposed helmet and Kestrel 5400 heat stress monitor.

From the monitored variables, considered heat stress indices were evaluated based on the mathematical expressions embedded in the sketch code. For WBGT assessment, ABM approximation model (Australian Bureau of Meteorology 2010) has been utilized in the case of the proposed safety helmet, while WBGT standard expression (ISO 7243 2017) was used for the equipment-based monitoring. Higher heat stress exposure levels were attributable to outdoor work condition (location 2), with respective heat indices exceeding the threshold limit values (TLVs). Although indoor work conditions (i.e., location 1 and location 3) also recorded harsh thermal exposure levels depending on the measured environmental variables. Figure 5 describes the boxplots for evaluated heat stress indices under the respective work conditions. Based on the risk range classification for considered heat stress indices; DI categorized the indoor work conditions (i.e., location 1 and location 3 ) under the high discomfort ("everyone feels discomfort" $\left(29^{\circ} \mathrm{C}\right.$ to $\left.<32{ }^{\circ} \mathrm{C}\right)$ ) risk zone, whereas outdoor work condition (location 2 ) under very high discomfort ("state of medical emergency" $\left(\geq 32{ }^{\circ} \mathrm{C}\right)$ ) risk category; for both proposed helmet and Kestrel 5400 respectively. WBGT $\left(\geq 30{ }^{\circ} \mathrm{C}\right)$, HI $\left(41{ }^{\circ} \mathrm{C}\right.$ to $\left.<54{ }^{\circ} \mathrm{C}\right)$, and FITS $\left(\geq 38^{\circ} \mathrm{C}\right)$ indices classified all respective work conditions under the danger risk category with average exposure values exceeding the TLVs (while higher heat exposure values were associated with the outdoor work than indoor work conditions). From measured physiological variables, higher values of CBT, ST, and HR were associated 

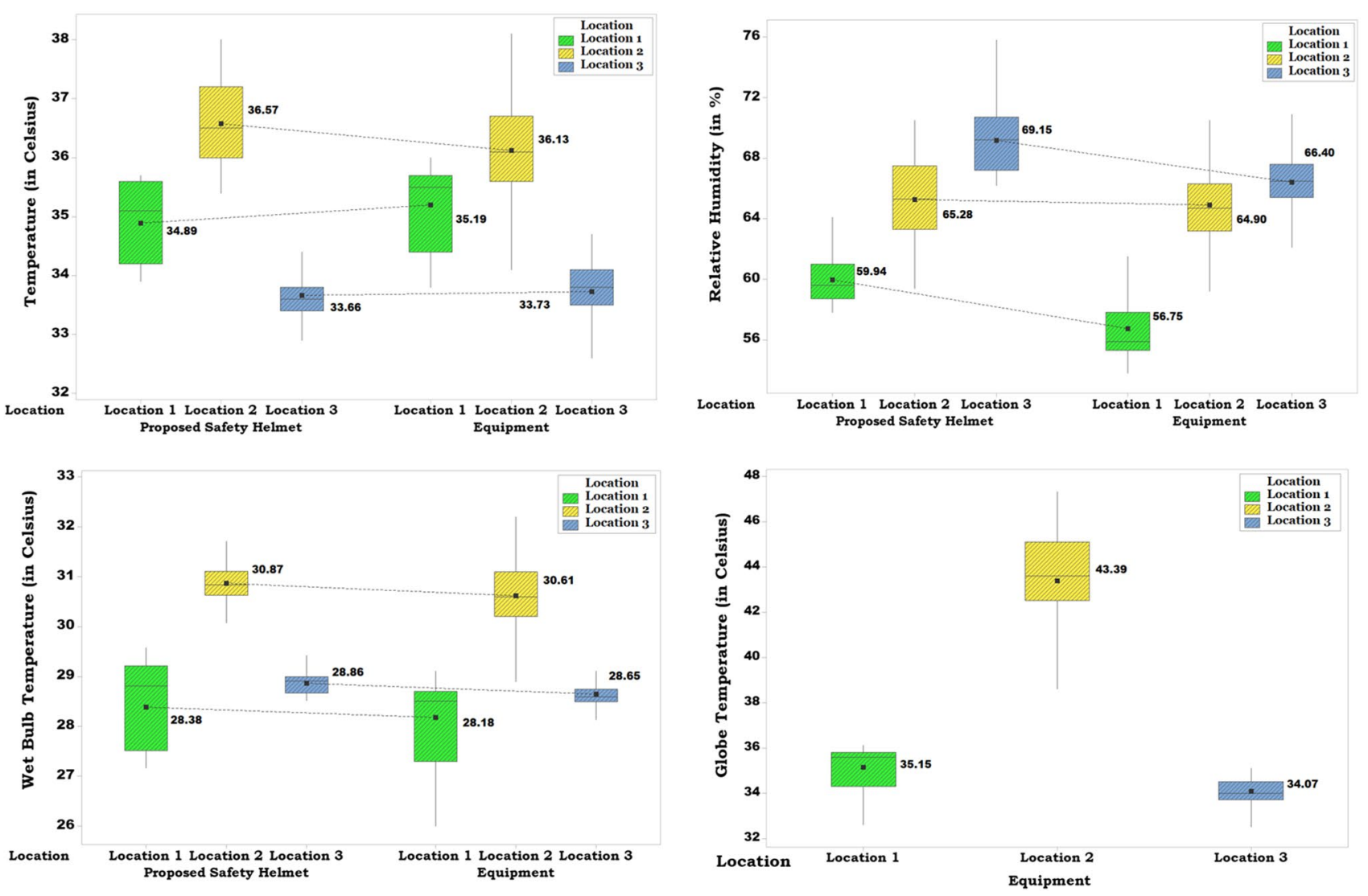

Fig. 4 Boxplot graphs for monitored environmental variables under different work locations

with the outdoor work (shoveling task; heavy workload activity) followed by moderate (indoor) and light (indoor) work activity. However, monitored blood pressure values (systolic and diastolic) showed slight variations under the respective work locations. Figure 6 illustrates the measured physiological variables for users engaged in specific work activities under the selected work conditions. Bivariate correlation analysis (Pearson product-moment correlation) was used to measure the association (at a significance level of 0.05 ; confidence interval $=95 \%$ ) among evaluated heat stress indices and physiological variables, as depicted in Table 4. Results revealed strong positive associations $(p$-value $<0.01$ ) among the respective heat stress indices.

\section{Discussion of findings}

Monitored environmental variables showed notable variations among the respective work environments. Results revealed higher wet-bulb temperature recorded under the outdoor work location than indoor work locations, which may be attributable to the combined effect of higher ambient temperature and humidity values. Also, higher globe temperature was associated with the outdoor work location (mean (SD): $43.39^{\circ} \mathrm{C}(2.364)$; range: $33.6-47.3{ }^{\circ} \mathrm{C}$ ), indicating direct exposure to solar radiation.

Slight variations were observed among the monitored environmental variables for the proposed safety helmet and Kestrel 5400 under the same work location. These variations may be accountable to several factors like air velocity, sensor sensitivity w.r.t work location, radiant effects, and resolution/accuracy levels, resulting in fluctuations among measured values for respective units. Evaluated indices showed higher heat risk exposure levels under the outdoor location compared to the other two indoor work locations. Slight variations were observed among the evaluated heat stress indices (i.e., DI, HI, FITS; except for ABM WBGT approximation) for the individual monitoring units (i.e., proposed safety helmet and Kestrel 5400). However, heat stress evaluations for the respective units conform to similar risk category levels under the targeted work location. Some of these variations could be related to the evaluation criteria/ expressions used for determining the wet-bulb temperature values.

Based on the risk range classifications for considered heat stress indices, i.e., WBGT, DI, HI, FITS (as illustrated in Table 1), the program code indicated corresponding risk exposure levels associated with the concerned work 

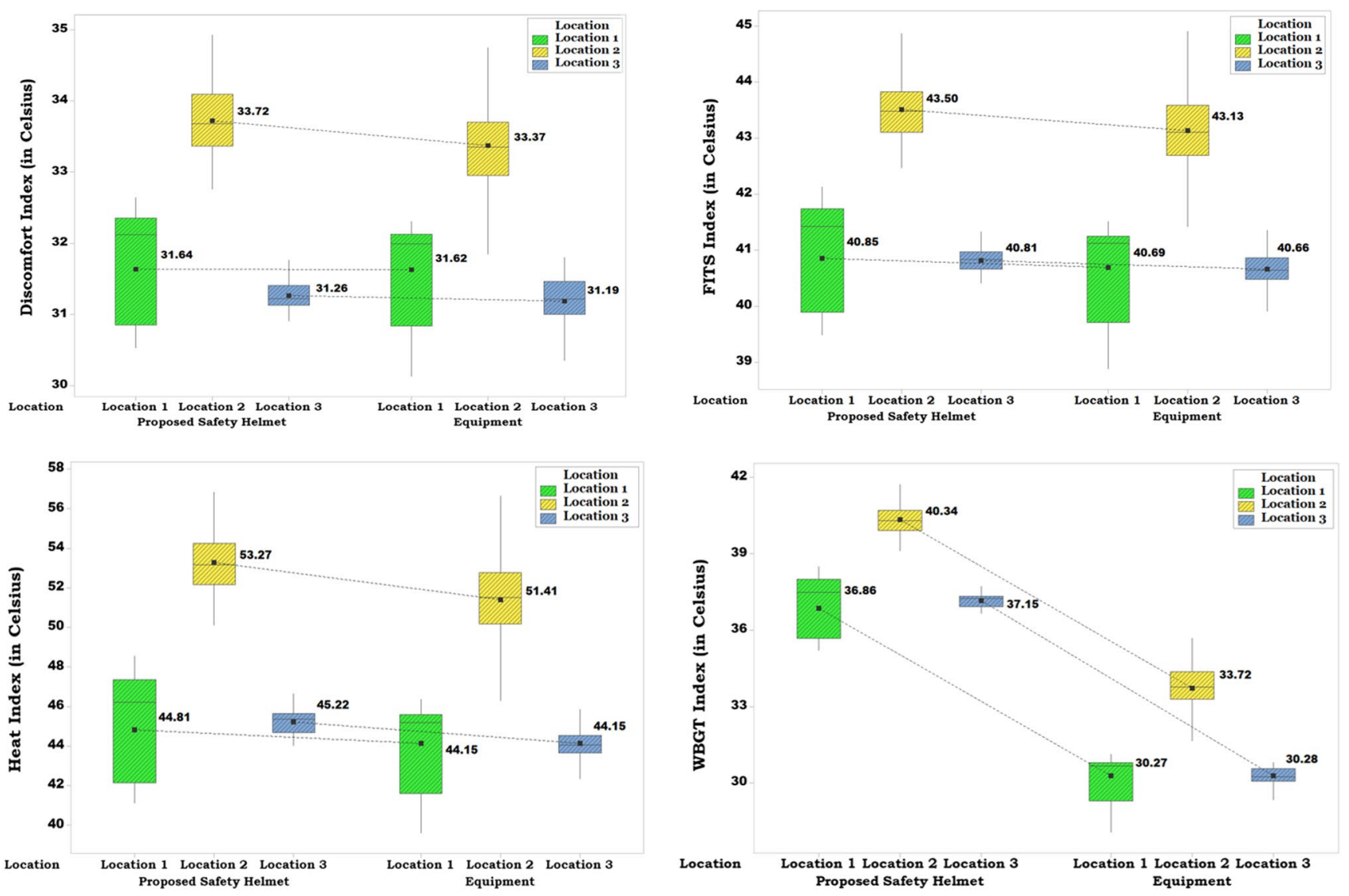

Fig. 5 Boxplot graphs for evaluated heat stress indices under different work locations

environments. WBGT values obtained by the ABM approximation model overestimated the heat exposure levels (under all three work locations) compared to standard WBGT expression. The ABM WBGT approximation yielded much higher heat stress exposure values than the standard WBGT, which may be a study limitation. As the ABM model solely relies on two input variables (i.e., $T_{a}$ and $R H$ ), the absence of other dominant factors (i.e., radiant effects, air velocity, clothing worn) could result in these variations/over-estimation. However, some correction factor could also be implemented to rectify this limitation. These variations could be in compliance with previous research findings (Lemke and Kjellstrom 2012; Grundstein and Cooper 2018), suggesting that approximations provided by the ABM model could under-estimate/over-estimate the WBGT values if standard assumptions are not fulfilled.

Strong associations $(p$-value $<0.01)$ were found among respective heat stress indices. For WBGT, highest correlation was observed with FITS $(r=0.979)$ followed by DI $(r=0.948)$ and HI $(r=0.931)$ indices. Figure 7 describes the scatter plots with linear regression lines depicting the relationship between WBGT and other considered indices. Results revealed a strong relationship among WBGT and
FITS $\left(R^{2}\right.$-value $\left.=0.959\right)$ followed by DI $\left(R^{2}\right.$-value $\left.=0.899\right)$ indices, although the least association with HI $\left(R^{2}\right.$ value $=0.867)$. Study results suggest that these direct indices (relatively simpler ones as respective expressions mostly rely on $T_{a}$ and $R H$ derived values; without requiring cumbersome evaluations and sophisticated costlier equipment) may be considered an adequate substitute in assessing the workplace thermal ambience. Observed results could be consistent with previous research studies (Moran and Pandolf 1999; Epstein and Moran 2006; Alfano et al. 2010), indicating strong associations between WBGT and other direct heat stress indices, proving their worth in assessing thermal work environments. Although, fewer limitations are present due to the absence of a few dominant factors like radiation effects, air-velocity; which could be sorted out by considering several heat stress indices at a time better suiting the targeted thermal ambience.

Results revealed the rise in users' physiological parameters (CBT, ST, and HR) under the heavy workload activity (shoveling task; outdoor location) followed by moderate workload (hacksaw cutting task; indoor location). However, the least values were observed for light workload activity (drilling task; indoor location). The observed rise indicates 

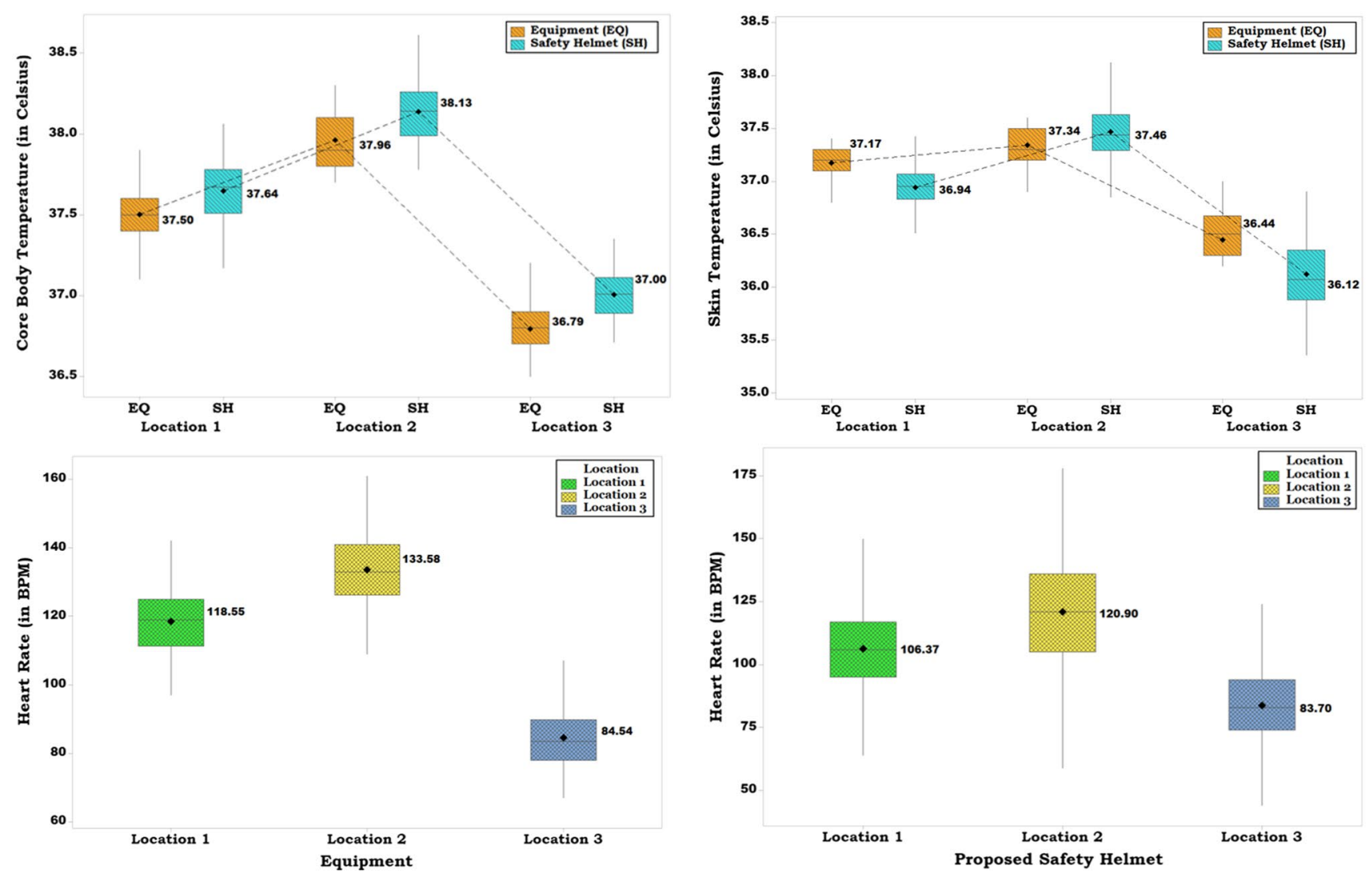

Fig. 6 Boxplot graphs for measured physiological variables under different work locations

Table 4 Bivariate correlation analysis for considered heat stress parameters

\begin{tabular}{llllllllll}
\hline & WBGT & DI & FITS & HI & CBT & ST & HR & BP $^{\$}$ & BP $^{\#}$ \\
\hline WBGT & & $0.948^{*}$ & $0.979^{*}$ & $0.931^{*}$ & $0.761^{*}$ & $0.653^{*}$ & $0.680^{*}$ & 0.217 & 0.106 \\
DI & $0.948^{*}$ & & $0.979^{*}$ & $0.958^{*}$ & $0.850^{*}$ & $0.742^{*}$ & $0.743^{*}$ & 0.244 & 0.115 \\
FITS & $0.979^{*}$ & $0.979^{*}$ & & $0.961^{*}$ & $0.781^{*}$ & $0.653^{*}$ & $0.663^{*}$ & 0.219 & 0.107 \\
HI & $0.931^{*}$ & $0.958^{*}$ & $0.961^{*}$ & & $0.767^{*}$ & $0.619^{*}$ & $0.624^{*}$ & 0.210 & 0.103 \\
CBT & $0.761^{*}$ & $0.850^{*}$ & $0.781^{*}$ & $0.767^{*}$ & & $0.822^{*}$ & $0.796^{*}$ & 0.228 & 0.088 \\
ST & $0.653^{*}$ & $0.742^{*}$ & $0.653^{*}$ & $0.619^{*}$ & $0.822^{*}$ & & $0.792^{*}$ & 0.022 & -0.110 \\
HR & $0.680^{*}$ & $0.743^{*}$ & $0.663^{*}$ & $0.624^{*}$ & $0.796^{*}$ & $0.792^{*}$ & & $0.455^{*}$ & 0.257 \\
BP $^{\$}$ & 0.217 & 0.244 & 0.219 & 0.210 & 0.228 & 0.022 & $0.455^{*}$ & & $0.837^{*}$ \\
BP $^{\#}$ & 0.106 & 0.115 & 0.107 & 0.103 & 0.088 & -0.110 & 0.257 & $0.837^{*}$ & \\
\hline
\end{tabular}

* Correlation significant at 0.01 level; ${ }^{\$}$ systolic blood pressure; ${ }^{*}$ diastolic blood pressure the heat strain experienced by the exposed user under the respective thermal work conditions. Findings suggest that the workload category may also influence the heat strain experienced by the exposed user under the targeted thermal work environment. Higher variations were observed for the proposed safety helmet among the measured pulse rate (standard deviation indicated wider spread in monitored HR values) compared to measured HR using standard equipment. However, an increasing trend was observed among the recorded HR values based on the respective workload (varying from light to heavy). Although, fewer variations were detected among the measured blood pressure values under the targeted work locations. Bivariate correlation analysis showed a strong positive relationship among the measured physiological parameters (CBT, ST, and HR) and evaluated heat stress indices ( $p$-value $<0.01)$, except for BP (systolic and diastolic). For CBT, highest positive association was observed with DI $(r=0.850)$ followed by FITS $(r=0.781)$, HI $(r=0.767)$, and WBGT $(r=0.761)$. For HR, discomfort index showed the strongest association 

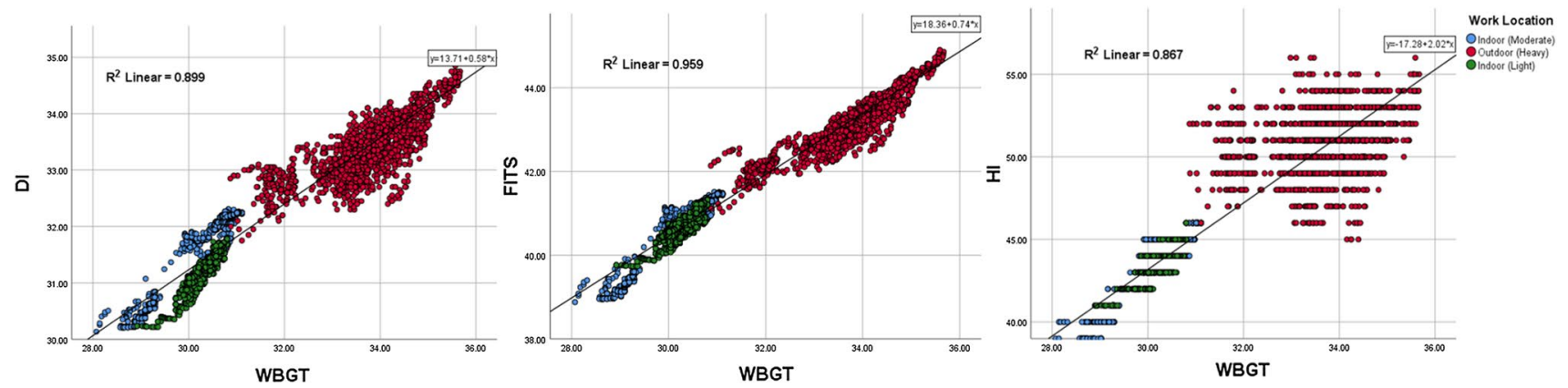

Fig. 7 Scatterplots and linear regression lines for respective indices w.r.t WBGT

( $r=0.743)$ followed by WBGT $(r=0.680)$, FITS $(r=0.663)$, and HI $(r=0.624)$. Also, ST showed highest association with DI $(r=0.742)$ followed by WBGT $(r=0.653)$, FITS $(r=0.653)$, and HI $(r=0.619)$. However, blood pressure values showed no significant association $(p$-value $>0.05)$ with the evaluated heat stress indices, while only a significant relationship for systolic blood pressure was detected with HR $(r=0.455)$.

Proposed design intervention could be beneficial in keeping exposed users well aware of the prevalent thermal work conditions/risk exposure levels at the individual level (as depicted in Fig. 8). This may be helpful for the exposed user in planning necessary actions/preventive measures such as regular fluid intake to stay well hydrated, job rotation, maintaining work-rest periods, and prioritizing the crucial thermal work locations requiring urgent remedial controls.

\section{Study limitations}

Few limitations associated with this study have been identified. The first study limitation was the smaller sample size; due to the COVID-19 pandemic, it was not feasible to perform this study with larger sample size. However, futuristic research would be conducted with a larger sample for more in-depth analysis and better insights into the current sensor-based approach. In the present study, all involved participants (male university students) were unacclimatized users. So, a study could also be conducted considering acclimatized persons having appropriate work experience under the actual work conditions (with user/worker wearing the proposed safety helmet while performing their routine work activities) like construction sites, foundries, and other indoor manufacturing units. Higher variations were observed

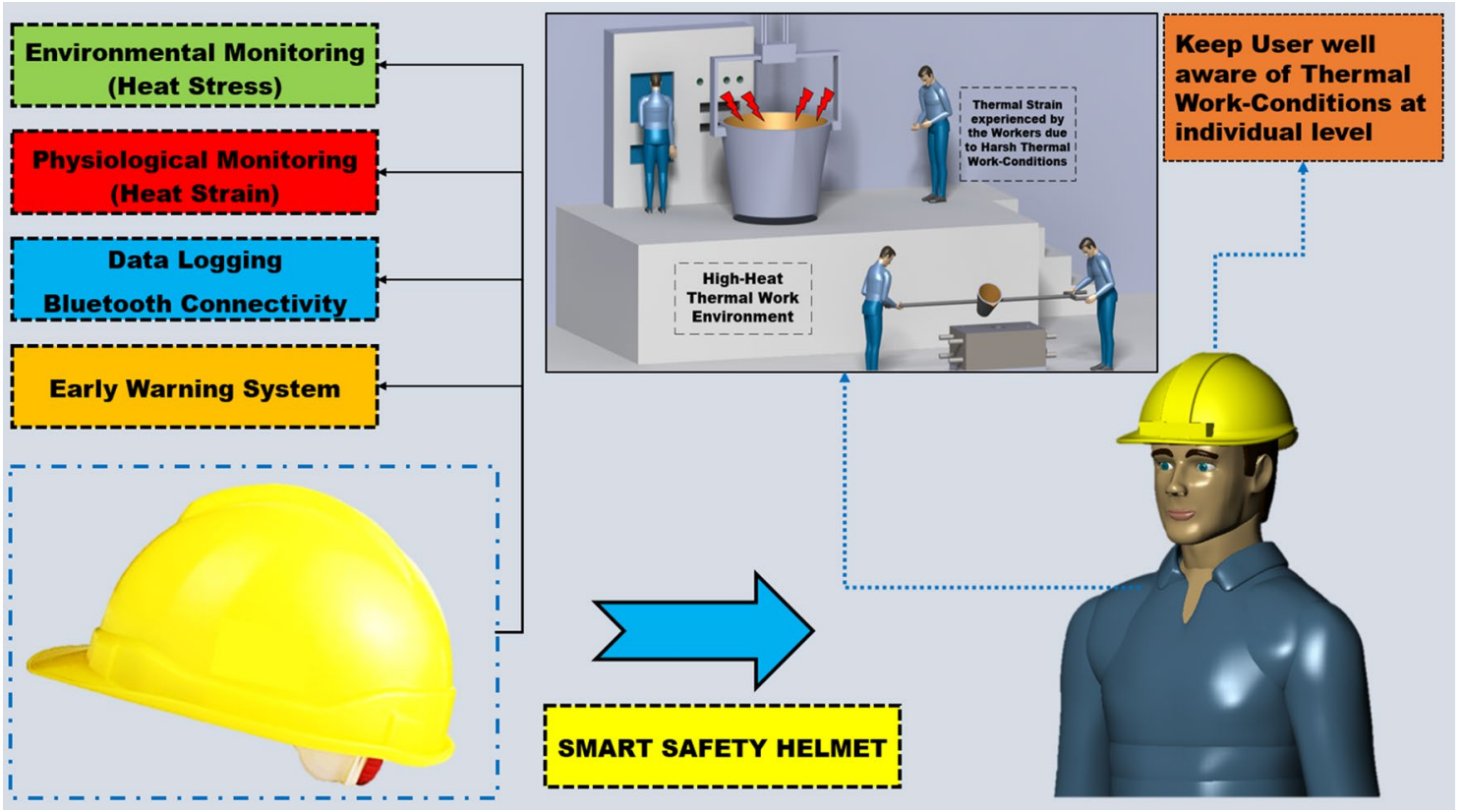

Fig. 8 Proposed safety helmet as a site-specific control intervention 
during sensor-based heart rate monitoring, which may be considered accountable to sensor placement and repetitive physical movements associated with the work operations. However, a futuristic study with a better placement design for heart rate sensor could provide more valuable results. So, a study could also be conducted keeping these shortcomings in mind.

\section{Conclusion}

Analyzing heat exposure levels under a specific work environment requires expensive monitoring equipment, which may not be cost-effective in most workplaces (especially in developing countries). With the emergence of modernistic sensors, attentiveness has arisen in generating facilities for concise data monitoring and analysis at a lower cost, with subsequent potential benefits like energy savings, reliability, compactness, and easier integration capability. With recent technological advancements, respective implementation concerns are gaining importance in industrialized developing countries to keep the targeted audience aware of the prevalent thermal work conditions.

Present work unveiled a novel approach (productive role of the sensor-based prototype) for analyzing heat stress exposures under different work conditions (with users' performing specific work activities). The proposed safety helmet could effectively monitor the environmental variables (dry-bulb temperature, relative humidity, wet-bulb temperature), respective heat stress indices (discomfort index, fighter index of thermal stress, and heat index), and users' physiological variables (eardrum temperature as an indicator of core body temperature, skin temperature, and heart rate). Results revealed notable variations among the monitored heat stress parameters under the targeted work environments, indicating that the proposed prototype was sensitive w.r.t the thermal ambience and physical work activity performed. For WBGT, the highest correlation was detected with FITS followed by DI and HI indices; indicating these direct indices as adequate substitutes for assessing the workplace thermal ambience without requiring cumbersome evaluations and costlier equipment. Also, strong positive associations were observed between the measured physiological parameters (CBT, ST, and HR) and evaluated heat stress indices. Research findings suggest that the demonstrated approach could be an effective site-specific solution for monitoring the prevalent thermal conditions under the targeted work environment. It may be implemented as a risk-based early warning detection system generating alarms/signals as the monitored values exceed the desired permissible limits.

Acknowledgments The authors wish to thank all who assisted in conducting this work.
Funding This study received no specific grant from any funding agency in the public, commercial, or not-for-profit sectors.

\section{Declarations}

Conflict of interest The author(s) declare(s) that there is no conflict of interest with any financial organization regarding the subject matter or material discussed in this manuscript.

Ethical approval All procedures performed in studies involving human participants were in accordance with the ethical standards of the institutional and/or national research committee and with the 1964 Helsinki declaration and its later amendments or comparable ethical standards. The study protocol was approved by the student research committee (SRC) of production and industrial engineering department, Punjab Engineering College, Chandigarh [Reference number: PEC/PED/38A].

Informed consent All participants were informed about the study objectives and written consent was obtained.

\section{References}

Alfano FRDA, Palella BI, Riccio G (2010) Thermal environment assessment reliability using temperature-humidity indices. Ind Health 49(1):95-106. https://doi.org/10.2486/indhealth.MS1097

Aritan AE (2019) Investigation of thermal comfort conditions in a travertine processing plant by using thermal comfort indices. Int J Environ Sci Technol 16(9):5285-5288. https://doi.org/10.1007/ s13762-019-02378-4

Aryal A, Becerik-Gerber B (2019) A comparative study of predicting individual thermal sensation and satisfaction using wrist-worn temperature sensor, thermal camera and ambient temperature sensor. Build Environ 160:106223. https://doi.org/10.1016/j.buildenv. 2019.106223

Australian Bureau of Meteorology (2010) Thermal Comfort observations. [Online]. http://www.bom.gov.au/info/thermal_stress/

Blazejczyk K, Epstein Y, Jendritzky G, Staiger H, Tinz B (2012) Comparison of UTCI to selected thermal indices. Int J Biometeorol 56(3):515-535. https://doi.org/10.1007/s00484-011-0453-2

BS EN ISO 8996:2004 (2004) Ergonomics of the thermal environment-determination of metabolic rate

BS EN ISO 9920:2009 (2009) Ergonomics of the thermal environmentEstimation of thermal insulation and water vapor resistance of a clothing ensemble

Chen ST, Lin SS, Lan CW, Hsu HY (2018) Design and development of a wearable device for heat stroke detection. Sensors 18(1):1-17. https://doi.org/10.3390/s18010017

Das S, Subudhi S (2021) A review on different methodologies to study thermal comfort. Int J Environ Sci Technol. https://doi.org/10. 1007/s13762-021-03210-8

Das S, Pal S, Mitra M (2017) Arduino-based noise robust online heartrate detection. J Med Eng Technol 41(3):170-178. https://doi.org/ 10.1080/03091902.2016.1271044

Deniz M, de Sousa KT, Gomes IC, Fabro JA, do Vale MM, Dittrich JR (2021) Development and application of an autonomous data logger to measure environmental variables in livestock farming. Int J Environ Sci Technol. doi:https://doi.org/10.1007/ s13762-021-03734-z

Devi S, Roy S (2017) Physiological measurement platform using wireless network with Android application. Inform Med Unlocked 7:1-13. https://doi.org/10.1016/j.imu.2017.02.001 
Djongyang N, Tchinda R, Njomo D (2010) Thermal comfort: a review paper. Renew Sustain Energy Rev 14(9):2626-2640. https://doi. org/10.1016/j.rser.2010.07.040

Epstein Y, Moran DS (2006) Thermal comfort and the heat stress indices. Ind Health 44(3):388-398. https://doi.org/10.2486/indhealth. 44.388

Fahed AK, Ozkaymak M, Ahmed S (2018) Impacts of heat exposure on workers' health and performance at steel plant in Turkey. Eng Sci Technol Int J 21(4):745-752. https://doi.org/10.1016/j.jestch. 2018.05.005

Giahi O, Darvishi E, Aliabadi M, Khoubi J (2016) The efficacy of radiant heat controls on workers' heat stress around the blast furnace of a steel industry. Work 53(2):293-298. https://doi.org/10.3233/ wor- 152104

Grundstein A, Cooper E (2018) Assessment of the Australian Bureau of Meteorology wet bulb globe temperature model using weather station data. Int J Biometeorol 62(12):2205-2213. https://doi.org/ 10.1007/s00484-018-1624-1

Havenith G, Fiala D (2011) Thermal indices and thermophysiological modeling for heat stress. Compr Physiol 6(1):255-302. https://doi. org/10.1002/cphy.c140051

International Organization for Standardization (ISO) (2017) ISO 7243, Ergonomics of the thermal environment-assessment of heat stress using the WBGT (wet bulb globe temperature) index

Jafari MJ, Pirposhteh EA, Dehghan SF, Khodakarim S, Jafari M (2020) Relationship between heat stress exposure and some immunological parameters among foundry workers. Int J Biometeorol 64(5):853-861. https://doi.org/10.1007/s00484-020-01874-4

Jha A, Tukkaraja P (2020) Monitoring and assessment of underground climatic conditions using sensors and GIS tools. Int J Min Sci Technol 30(4):495-499. https://doi.org/10.1016/j.ijmst.2020.05. 010

Kjellstrom T, Holmer I, Lemke B (2009) Workplace heat stress, health and productivity-an increasing challenge for low and middleincome countries during climate change. Glob Health Action 2(1):2047. https://doi.org/10.3402/gha.v2i0.2047

Kjellstrom T, Maître N, Saget C, Otto M, Karimova T (2019) Working on a warmer planet: the effect of heat stress on productivity and decent work. Geneva: International Labour Organization (ILO)

Krishnamurthy M, Ramalingam P, Perumal K, Kamalakannan LP, Chinnadurai J, Shanmugam R, Venugopal V (2017) Occupational heat stress impacts on health and productivity in a steel industry in southern India. Saf Health Work 8(1):99-104. https://doi.org/ 10.1016/j.shaw.2016.08.005

Lemke B, Kjellstrom T (2012) Calculating workplace WBGT from meteorological data: a tool for climate change assessment. Ind Health 50(4):267-278. https://doi.org/10.2486/indhealth.MS1352

Moran DS, Pandolf KB (1999) Wet bulb globe temperature (WBGT)to what extent is GT essential? Aviat Space Environ Med 70(5):480-484

Nunneley SA, Stribley RF (1978) Fighter index of thermal stress: relation to weather conditions at ATC and TAC bases. School of Aerospace Medicine Brooks AFB TX
Parsons K (2006) Heat stress standard ISO 7243 and its global application. Ind Health 44(3):368-379. https://doi.org/10.2486/indhe alth. 44.368

Parsons K (2019) Human Heat Stress. CRC Press, New York

Rabeiy RE (2019) Evaluation of indoor heat stress on workers of bakeries at Assiut City. Egypt Int J Environ Sci Technol 16(6):26372642. https://doi.org/10.1007/s13762-018-1839-z

Rothfusz LP, Headquarters NSR (1990) The heat index equation (or, more than you ever wanted to know about heat index). Fort Worth, Texas: National Oceanic and Atmospheric Administration, National Weather Service, Office of Meteorology, 9023

Sawka MN, Friedl KE (2018) Emerging wearable physiological monitoring technologies and decision aids for health and performance. J Appl Physiol 124:430-431. https://doi.org/10.1152/japplphysi ol.00964.2017

Sharma M, Kataria KK, Suri NM, Kant S (2020) Monitoring respirable dust exposure in fettling work environment of a foundry: a proposed design intervention. Int J Saf Secur Eng 10(6):759-767. https://doi.org/10.18280/ijsse.100606

Sohar E, Tennenbaum J, Robinson N (1962) A comparison of the Cumulative Discomfort Index (Cum. DI) and Cumulative Effective Temperature (Cum. ET), as obtained by meteorological data. Int Biometeorol Pergamon. https://doi.org/10.1016/B978-0-08009683-4.50052-8

Standard ISO (2004) ISO 9886: Ergonomics-Evaluation of Thermal Strain by Physiological Measurements. International Standard Organization 1-21

Steadman RG (1979) The assessment of sultriness. Part I: a temperature-humidity index based on human physiology and clothing science. J Appl Meteorol Climatol 18(7):861-873. https://doi.org/ 10.1175/1520-0450(1979)018<0861:TAOSPI > 2.0.CO;2

Stull R (2011) Wet-bulb temperature from relative humidity and air temperature. J Appl Meteorol Climatol 50(11):2267-2269. https:// doi.org/10.1175/JAMC-D-11-0143.1

Varghese BM, Hansen A, Bi P, Pisaniello D (2018) Are workers at risk of occupational injuries due to heat exposure? A comprehensive literature review. Saf Sci 110:380-392. https://doi.org/10.1016/j. ssci.2018.04.027

Venugopal V, Krishnamoorthy M, Venkatesan V, Jaganathan V, Shanmugam R, Kanagaraj K, Paul SF (2019) Association between occupational heat stress and DNA damage in lymphocytes of workers exposed to hot working environments in a steel industry in Southern India. Temperature 6(4):346-359. https://doi.org/10. 1080/23328940.2019.1632144

Venugopal V, Latha PK, Shanmugam R, Krishnamoorthy M, Srinivasan K, Perumal K, Chinnadurai JS (2020) Risk of kidney stone among workers exposed to high occupational heat stress: a case study from southern Indian steel industry. Sci Total Environ 722:137619. https://doi.org/10.1016/j.scitotenv.2020.137619 